\title{
Effect of Sodium Hypochlorite, EDTA, and Chitosan Solution on Corrosion and Quantity of Extruded Nickel Ions Using Two Rotary Instruments (In Vitro)
}

\author{
Eltica Oktavia ${ }^{1}$, Trimurni Abidin² ${ }^{2}$ Dennis Dennis ${ }^{3}$
}

\begin{abstract}
Aim: To compare the effect $2.5 \% \mathrm{NaOCl}, 17 \%$ ethylenediaminetetraacetic acid (EDTA), and $0.2 \%$ high molecular chitosan solution during root canal preparation using ProTaper Universal and iRace rotary file on corrosion of NiTi instrument and quantity of apically extruded nickel ions. Materials and methods: Twenty-four extracted human premolars were divided into 4 groups. Group I was the sample with root canal preparation using ProTaper Universal rotary file with $2.5 \% \mathrm{NaOCl}$ and $17 \% \mathrm{EDTA}$, group II was the sample using ProTaper Universal rotary file with $2.5 \% \mathrm{NaOCI}$ and $0.2 \%$ high molecular chitosan solution, group III was the sample using iRace rotary file with $2.5 \% \mathrm{NaOCl}$ and $17 \%$ EDTA, and group IV was the sample using iRace rotary file with $2.5 \% \mathrm{NaOCl}$ and $0.2 \%$ high molecular chitosan solution. After root canal preparation, the quantity of apically extruded nickel ions was evaluated using atomic absorption spectrophotometry (AAS). Instruments were evaluated for corrosion and surface defect using a scanning electron microscope.

Results: A combination of $2.5 \% \mathrm{NaOCl}$ and $0.2 \%$ high molecular chitosan solution caused significantly lower corrosion and surface defect in ProTaper Universal and iRace rotary files and also produced fewer extrusions of nickel ions compared to a combination of $2.5 \% \mathrm{NaOCl}$ and $17 \%$ EDTA. The mean value of corrosion and surface defect scores on iRace was lower and also resulted in less extrusion of nickel ions compared to ProTaper Universal rotary.

Conclusion: $0.2 \%$ high molecular chitosan solution can be developed as a chelating material, an alternative to EDTA.

Keywords: $17 \%$ EDTA, $0.2 \%$ high molecular chitosan solution, $2.5 \% \mathrm{NaOCl}$, iRace, ProTaper Universal rotary file.

World Journal of Dentistry (2019): 10.5005/jp-journals-10015-1638
\end{abstract}

\section{INTRODUCTION}

Chemomechanical preparation of the root canal includes both mechanical instrumentation and antibacterial irrigation and is principally directed toward the elimination of microorganisms from the root canal system. ${ }^{1}$ The NiTi instrument was first introduced as a manual instrument in 1988. Considering its properties of superior elasticity and resistance to torsional fracture, Walia introduced nickel titanium endodontic rotary files to the field of endodontics. ${ }^{2}$ The specific design characteristics, such as cross-sectional geometry, tip design, taper, rake angle, helix angle, pitch, and radial land, vary and will influence the flexibility, cutting efficiency, and torsional resistance of the instrument. ${ }^{1}$

Some of the rotary files that are widely used today are ProTaper Universal (Dentsply, Maillefer, Ballaigues, Switzerland) and iRace (FKG, La Chaux-de-Fonds, Switzerland) rotary files. ProTaper Universal rotary is a multiple file system with a progressive taper and has a convex triangular cross-section design. ${ }^{3}$

The iRace (instrument reamer with alternating cutting edges) rotary file has been recently introduced as a simplified sequence of the Race system. This instrument has a sharp cutting edge (triangular cross-section) design without radial land, positive rake angle, and electrochemical surface treatment. The surface of new ProTaper and iRace files has an almost similar amount of nickel, titanium, and oxygen components. ${ }^{2,4}$

Sodium hypochlorite $(\mathrm{NaOCl})$ was recommended as an endodontic irrigant by Coolidge in $1919 .{ }^{5}$ Various concentrations of $\mathrm{NaOCl}(0.5-6 \%)$ are used for root canal irrigation. ${ }^{6}$ It has the unique ability to dissolve necrotic tissue and the organic components of the smear layer, but cannot dissolve inorganic dentin particles
${ }^{1-3}$ Department of Conservative Dentistry, Faculty of Dentistry, Universitas Sumatera Utara, Medan, North Sumatera, Indonesia; Center of Excellence, Green Chitosan and Advanced Material, Universitas Sumatera Utara, Medan, Indonesia

Corresponding Author: Trimurni Abidin, Department of Conservative Dentistry, Faculty of Dentistry, Universitas Sumatera Utara, Medan, North Sumatera, Indonesia; Center of Excellence, Green Chitosan and Advanced Material, Universitas Sumatera Utara, Medan, Indonesia, Phone: +62 81330230921, e-mail: triabidin@yahoo.com

How to cite this article: Oktavia E, Abidin T, et al. Effect of Sodium Hypochlorite, EDTA, and Chitosan Solution on Corrosion and Quantity of Extruded Nickel lons Using Two Rotary Instruments (In Vitro). World J Dent 2019;10(3):207-213.

Source of support: Nil

Conflict of interest: None

and thus cannot prevent the formation of a smear layer during instrumentation. ${ }^{7}$ A recognizably efficient protocol for removal of the smear layer is the use of $\mathrm{NaOCl}$ at concentrations ranging from $0.5 \%$ to $6 \%$ and $17 \%$ EDTA. ${ }^{8}$ EDTA refers to the chelating agent with the formula $\left(\mathrm{HO}_{2} \mathrm{CCH}_{2}\right)_{2} \mathrm{NCH}_{2} \mathrm{CH}_{2} \mathrm{~N}\left(\mathrm{CH}_{2} \mathrm{CO}_{2} \mathrm{H}\right)_{2}$. Nygaard-Ostby introduced EDTA to the field of endodontics, in 1957, and recommended using 15\% EDTA solution with a pH of 7.3. In endodontics, EDTA $15-17 \%$ is used as an irrigation solution. ${ }^{2,9}$

Although the combination of EDTA and $\mathrm{NaOCl}$ is the most recommended for optimal irrigation, this combination can cause dentinal erosion to the peritubular and intertubular areas of the dentine. Hulsmann and Hahn reported that the rough surface produced from these two irrigants might become a hiding place 
for bacteria and leads to microleakage. The combination of $\mathrm{NaOCl}$ and EDTA can also inhibit the reaction of chloramines from $\mathrm{NaOCl}$. Zaparolli stated that the combination of $\mathrm{NaOCl}$ and EDTA could significantly reduce root dentin microhardness. ${ }^{10-12}$

The side effects caused by the use of a combination of $\mathrm{NaOCl}$ and EDTA have prompted researchers to look for safer, more biocompatible, and more profitable alternative materials. Among these alternative materials, chitosan has been a very promising irrigant. Chitosan is poly(2-amino-2-deoxy- $\beta(1-4)$-D-glucopyranose) with the formula $\left(\mathrm{C}_{6} \mathrm{H}_{11} \mathrm{NO}_{4}\right)_{n}$ which can be obtained from chitin deacetylation. High molecular chitosan is chitosan with a molecular weight between 800,000-1,100,000 MW. Chitosan which has a degree of deacetylation of $84.20 \%$ and a molecular weight $893,000 \mathrm{MW}$ (high molecular weight) was the first one used in dentistry. 13,14

Falmini et al. showed that $0.2 \%$ chitosan solution was able to remove the smear layer and had almost the same effect as $15 \%$ EDTA. ${ }^{15}$ Ayu and Trimurni reported that $0.1 \%$ chitosan solution was able to remove the smear layer, but there was still a smear plug in the dentinal tubules while $0.2 \%$ chitosan solution showed complete removal of the smear layer. ${ }^{16}$ Pimenta showed that chitosan solution had chelating properties if used as an irrigant, but it can cause dentinal erosion even though it did not affect intertubular dentin. ${ }^{17}$ The development of chitosan as a root canal chelation material is expected to be an alternative irrigant to EDTA.

Even though the benefits of irrigants are essential for chemomechanical preparation, chemical and electrochemical aggressiveness of these solutions may damage the surface of the instruments. Many studies on the susceptibility of endodontic instruments toward corrosion in irrigation solution have been carried out. The corrosion process can be activated during chemomechanical preparation, chemical disinfection, and sterilization. ${ }^{18}$ The surface of $\mathrm{NiTi}$ instrument mainly consists of oxygen, carbon, and titanium oxides $\left(\mathrm{TiO}_{2}\right)$ with smaller amounts of nickel oxides ( $\mathrm{NiO}$ and $\mathrm{Ni}_{2} \mathrm{O}_{3}$ ) and nickel (Ni). Nickel ( $\mathrm{Ni}$ ) may dissolve more easily than titanium (Ti) because its oxide is not so stable. ${ }^{19}$

During the chemomechanical procedure, there is always the possibility of irrigation solution and intracanal debris being extruded beyond the apical foramen even when the working length $(\mathrm{WL})$ is controlled. ${ }^{20}$ Glassman reported that apical extrusion of endodontic irrigant routinely occurs in vivo. ${ }^{7}$ Numerous studies showed that all instrumentation systems produce apical extrusion. However, the type of instrumentation system affects the amount of apical extrusion. ${ }^{21}$

The release of nickel ions caused by corrosion in endodontic instruments extruded to the periradicular region causes unwanted reactions and corresponds to the corrosion rate. Nickel cannot be metabolized in the body and it is known as a haematotoxic, immunotoxic, neurotoxic, genotoxic, reproductive toxic, pulmonary toxic, nephrotoxic, hepatotoxic, and carcinogenic agent. ${ }^{22}$ Using instruments and irrigants can minimize the extrusion of nickel ions beyond the apical foramen and will be an advantage for patients and clinicians.

This study aims to compare the effect of $2.5 \% \mathrm{NaOCl}, 17 \%$ EDTA, and $0.2 \%$ high molecular chitosan solution during root canal preparation using ProTaper Universal and iRace rotary files on corrosion of NiTi instrument and quantity of apically extruded nickel ions.

\section{Materials and Methods}

Twenty-four freshly extracted human single-rooted mandibular premolars with mature apices and a curvature of $0^{\circ}-10^{\circ}$ were selected. The teeth were cleaned of debris and soft-tissue remnants and were stored in physiological saline until used in the study.
The working length established to $1 \mathrm{~mm}$ short of teeth length, and the teeth decoronated to obtain root segments $18 \mathrm{~mm}$ long and randomly assigned to four groups. Two coats of nail varnish were applied to the external surface of all roots, except $2 \mathrm{~mm}$ apical. Debris and irrigant collection was performed following the Myers and Montgomery method. Teeth was placed inside a glass tube filled with self-curing acrylic resin to obtain a hermetic seal. The teeth and glass tubes were shielded from the operator by a rubber dam during the instrumentation process. A bent 25 -gauge needle was forced into the tube's top as a drainage cannula to balance the air pressure inside and outside the tube. These tubes acted as collectors for the debris and irrigant evacuated through the foramen of the root during instrumentation. Endodontic access cavities were prepared with an Endo Access Bur (Dentsply Maillefer) in a high-speed handpiece, and pulpal remnants were extirpated using a broach.

Twenty-four extracted human premolars were divided into 4 groups. Group I was the sample with root canal preparation using ProTaper Universal rotary file with $2.5 \% \mathrm{NaOCl}$ and $17 \%$ EDTA, group II was the sample using ProTaper Universal rotary file with $2.5 \% \mathrm{NaOCl}$ and $0.2 \%$ high molecular chitosan solution, group III was the sample using iRace rotary file with $2.5 \% \mathrm{NaOCl}$ and $17 \%$ EDTA, and group IV was the sample using iRace rotary file with $2.5 \%$ $\mathrm{NaOCl}$ and $0.2 \%$ high molecular chitosan solution. Immediately after instrumentation, the tops with the attached teeth were removed from the collector tubes. The bottles were closed again with new tops. Files were subsequently cleaned in an ultrasonic bath for $400 \mathrm{~s}$, in absolute alcohol $96 \%$, and left for drying on a cotton pellet at room temperature and stored in sterile bottles. Bottles were coded to distinguish one another. Quantity of apically extruded nickel ions was evaluated using AAS and instruments were evaluated for corrosion and surface defect using a scanning electron microscope.

\section{AAS Procedure}

To each sample was added $20 \mathrm{~mL}$ of concentrated nitric acid and it was heated using an electric heater until the solution was almost dry $( \pm 10 \mathrm{~mL})$, then distilled aqua was added to the limit of $15 \mathrm{~mL}$. Making Ni standard solution with concentration 0.1:0.2:0.3:0.4:0.5 ppm and each absorbance was measured by AAS at wavelength $(\lambda) 231.90 \mathrm{~nm}$. The results of absorbance measurements were plotted against concentration to obtain a calibration curve of the Ni standard solution (Fig. 1), then samples were measured by AAS at wavelength ( $\lambda$ ) $231.90 \mathrm{~nm}$ for $\mathrm{Ni}$ analysis.

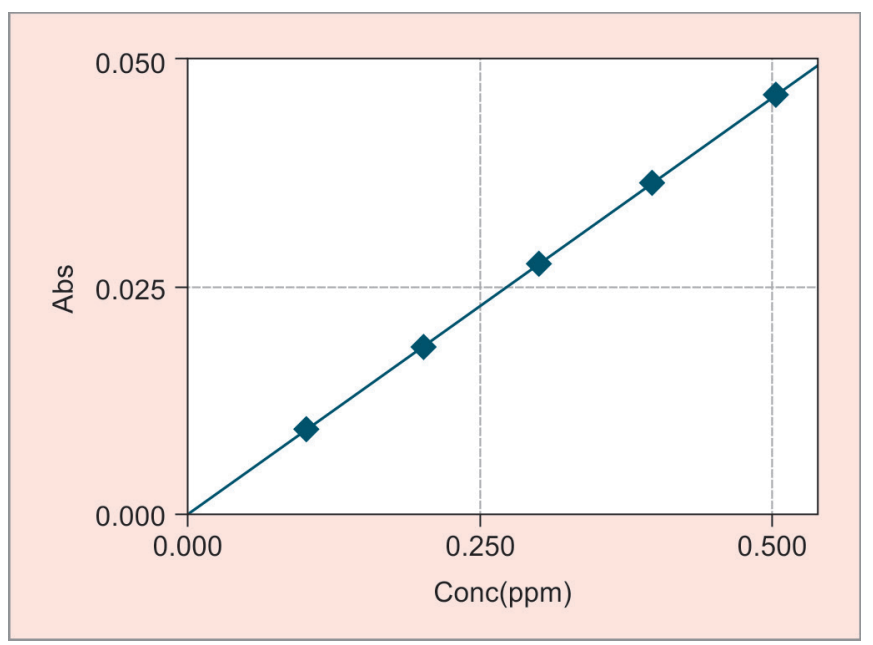

Fig. 1: Calibration curve of $\mathrm{Ni}$ standard solution 


\section{Scanning Electron Microscopy (SEM) Procedure}

The files were cut on the handle to equalize the surface. Files were mounted on SEM specimen mount stubs using double-sided carbon tape. Three files in each group were submitted for SEM evaluation with $1,000 \times$ magnification, then the images were compared with a new file.

\section{Results}

\section{Analysis of Quantity of Extruded Nickel lons Using AAS}

The mean value of quantity of nickel ions in all groups is presented in Table 1 and Figure 2. In Figure 2, the highest mean value of nickel ions was found in group I $(2.415 \mu \mathrm{g})$, which was samples using ProTaper Universal rotary file with $2.5 \% \mathrm{NaOCl}$ and $17 \%$ EDTA. The lowest mean value of nickel ions was found in group IV $(1.179 \mu \mathrm{g})$, which was samples using iRace with $2.5 \% \mathrm{NaOCl}$ and $0.2 \%$ high molecular chitosan solution.

Table 1: Mean value of nickel ions quantity between four groups

\begin{tabular}{lllll}
\hline Group & $\begin{array}{l}\text { Mean value } \\
(\mu \mathrm{g})\end{array}$ & $\begin{array}{l}\text { Standard } \\
\text { deviation }(\mu \mathrm{g})\end{array}$ & $\begin{array}{l}\text { Minimum } \\
(\mu \mathrm{g})\end{array}$ & $\begin{array}{l}\text { Maximum } \\
(\mu \mathrm{g})\end{array}$ \\
\hline I & 2.415 & 1.875 & 0.175 & 5.310 \\
II & 2.238 & 1.383 & 0.250 & 4.086 \\
III & 1.983 & 0.746 & 0.851 & 2.930 \\
IV & 1.179 & 0.228 & 0.928 & 1.458 \\
Total & 1.954 & 1.243 & 0.175 & 5.310 \\
\hline
\end{tabular}

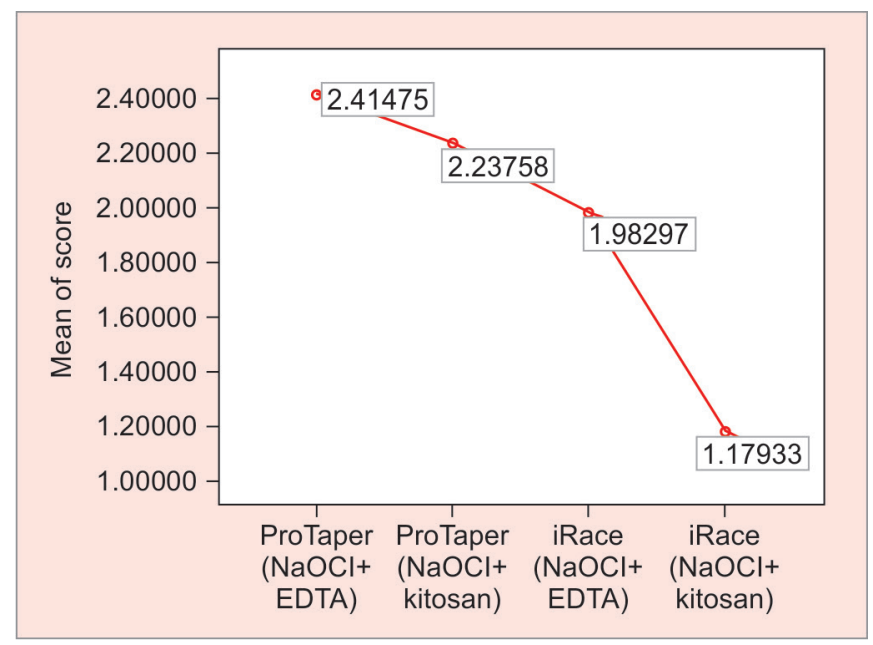

Fig. 2: Mean value based on four groups

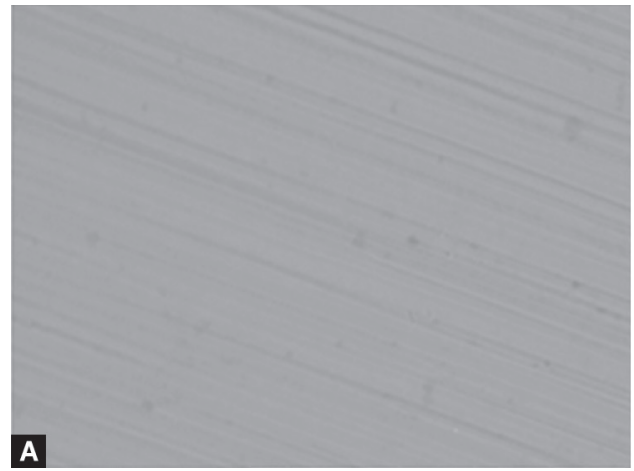

Figs 3A and B: (A) New ProTaper Universal rotary; (B) New iRace rotary

\begin{tabular}{lllll}
\multicolumn{5}{l}{ Table 2: LSD test of nickel ions quantity } \\
\hline Group & I & II & III & IV \\
\hline I & - & & & \\
II & 0.805 & - & & \\
III & 0.549 & 0.723 & - & \\
IV & 0.097 & 0.151 & 0.271 & - \\
\hline
\end{tabular}

The next step is the least significance difference (LSD) test. Least significance difference test results are presented in Table 2.

\section{Analysis of Corrosion and Surface Damage of the Instrument Using a SEM}

The results of SEM with 1,000× magnification on the surface of new ProTaper Universal and iRace rotary files as a control file are presented in Figure 3. In Figure 3, it can be seen that the surface of the new ProTaper Universal and iRace rotary file did not have defects such as pitting, corrosion, debris, etc. Then, samples A1, $A 3, A 4, B 1, B 5, B 6, C 1, C 4, C 6, D 2, D 4$, and D6 were evaluated using SEM (Figs 4 and 5).

The score for each sample was the sum of all changes noticed on the surface using SEM and assessed with a scoring system from Eggert et al. The Eggert et al. scoring system is presented in Table 3. Scores were given by two observers. Scores of corrosion and surface damage for each sample are presented in Table 4.

Based on the paired $t$ test, there was no difference in the scores between observer 1 and 2 ( $p$ value $=0.053>0.05$ ), so the data can be taken from observer 1 or 2 . Furthermore, the data were taken from the results of observer 1 . The mean values of corrosion and surface damage scores in all samples were calculated and are presented in Table 5 and Figure 6.

In Figure 6, the highest mean value of corrosion and surface damage scores was found in group I (36), which was samples using ProTaper Universal rotary file with $2.5 \% \mathrm{NaOCl}$ and $17 \%$ EDTA. The lowest mean value of corrosion and surface damage scores was found in group IV $(186,667)$, which was samples using iRace with $2.5 \% \mathrm{NaOCl}$ and $0.2 \%$ high molecular chitosan solution.

The next step is the LSD test. The results of the LSD test are presented in Table 6.

\section{Discussion}

NiTi instruments have a high risk of separation, mainly because of fatigue and torsional shear stress. One factor potentially limiting resistance to fatigue fracture is corrosion that may occur in the presence of irrigation solution. ${ }^{23}$ Corrosion patterns of $\mathrm{NiTi}$ alloy involved selective removal of nickel from the surface. ${ }^{24}$

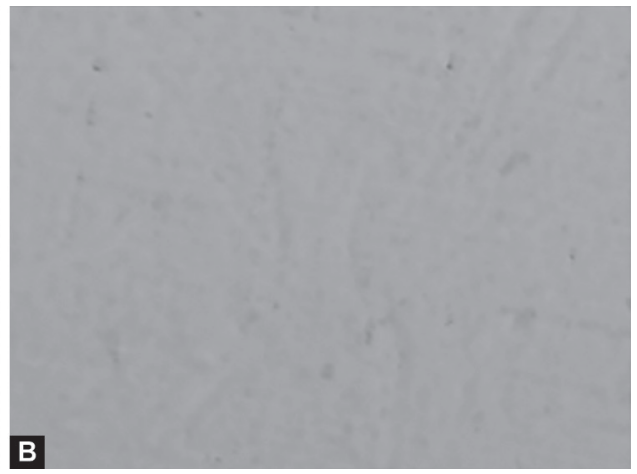



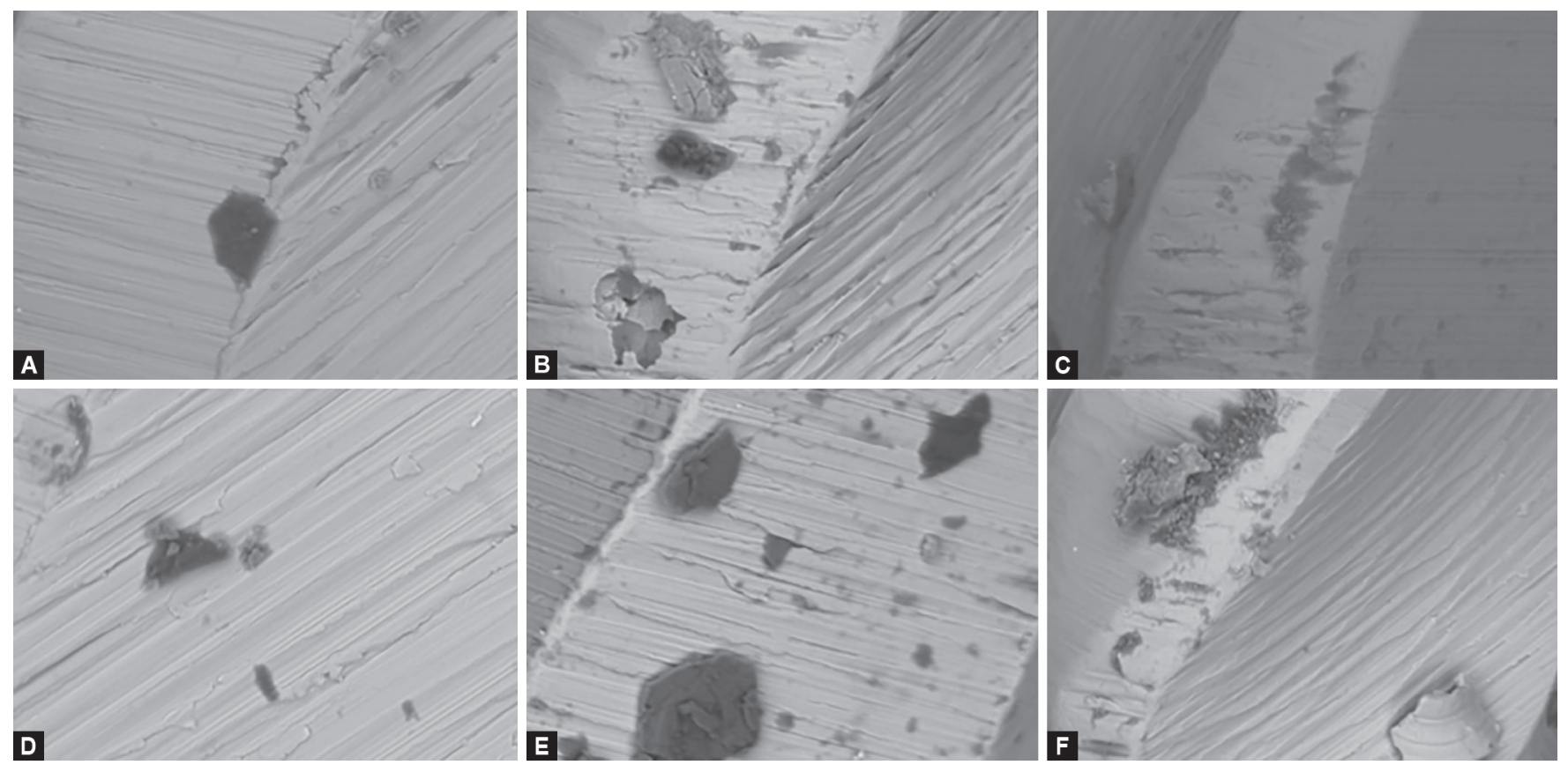

Figs 4A to F: (A) SEM results with 1,000× magnification in the sample A1; (B) Sample A3; (C) Sample A4; (D) Sample B1; (E) Sample B5; (F) Sample B6
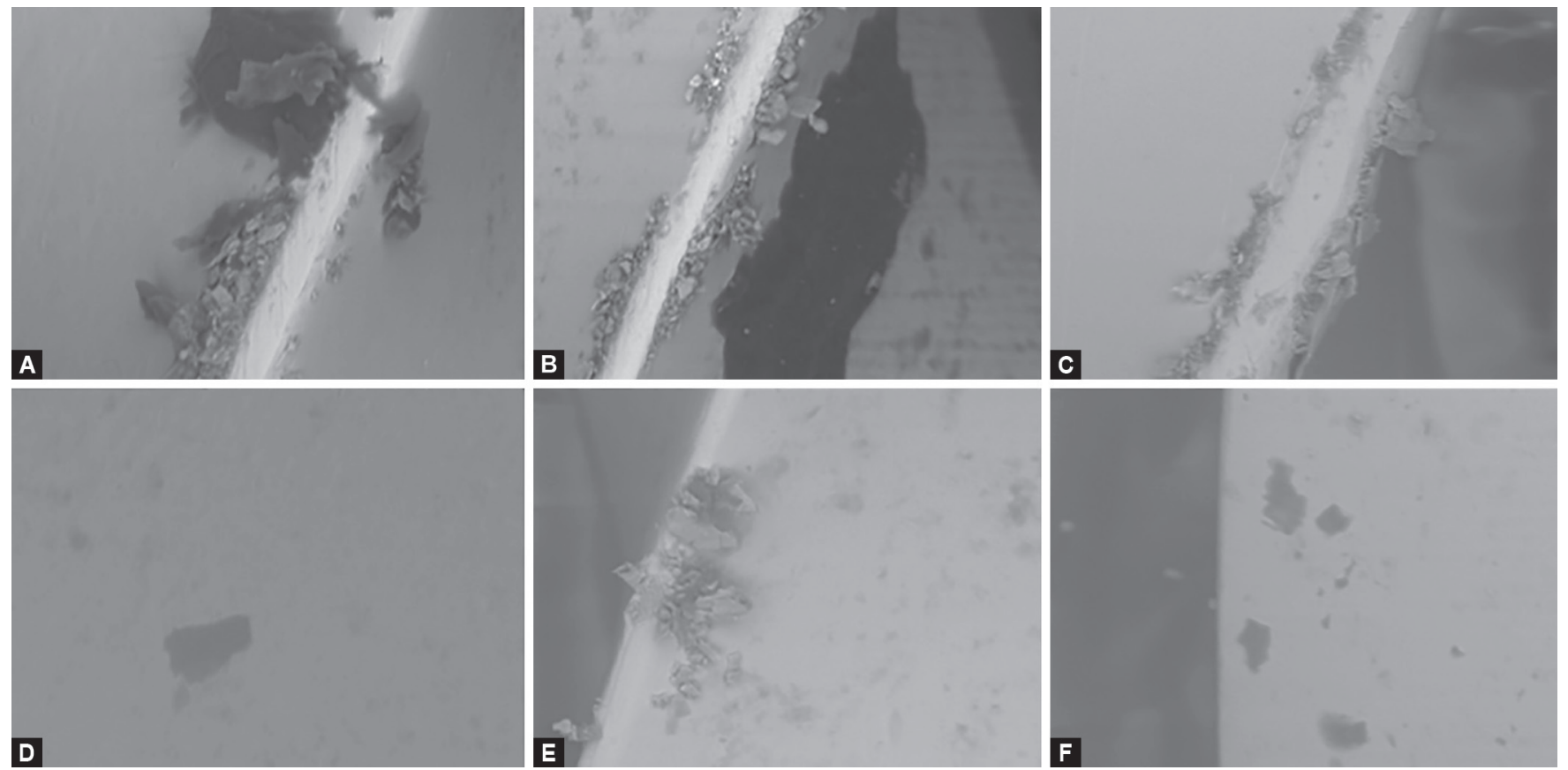

Figs 5A to F: (A) SEM results with 1,000× magnification in the sample C1; (B) Sample C4; (C) Sample C6; (D) Sample D2; (E) Sample D4; (F) Sample D6

Corrosion is generally associated with specific solutions; so far the most common is chloride. It is known that $\mathrm{NaOCl}$, a chlorinecontaining solution, is corrosive to metals. Certain conditions, such as high concentrations of chloride, can interfere with a given alloy's ability to reform a passivating film. ${ }^{18,24}$ Popovic et al. indicated that $5.25 \% \mathrm{NaOCl}$ used as root canal irrigants caused severe corrosion on the surface of the $\mathrm{Ni}-\mathrm{Ti}$ and stainless steel endodontic files. ${ }^{18}$

In this study, the $\mathrm{pH}$ of each irrigant was measured, and the result showed that $\mathrm{NaOCl} \mathrm{pH}$ was alkaline and EDTA and high molecular chitosan solution $\mathrm{pH}$ were neutral. The contact time between the rotary instrument and irrigant on the root canal was
3-5 seconds. The result of this study indicated that the combination of $2.5 \% \mathrm{NaOCl}$ and $17 \%$ EDTA had a significantly higher corrosive effect compared to the combination of $2.5 \% \mathrm{NaOCl}$ and $0.2 \%$ high molecular chitosan solution in ProTaper Universal and iRace rotary file.

This result was in accordance with the results of earlier studies. Ametrano et al. showed that short-term contact with 17\% EDTA and $5 \% \mathrm{NaOCl}$ caused alterations on the surface of ProTaper rotary instruments. ${ }^{25}$ Prasad et al. confirmed that short-term contact with $17 \%$ EDTA and $5 \% \mathrm{NaOCl}$ could cause significant surface deterioration of ProTaper and iRace NiTi rotary files. ${ }^{2}$ In SES study, 
Table 3: Scoring system for corrosion and surface damage (Eggert et al.)

\begin{tabular}{cl}
\hline Score & Criteria \\
\hline 1 & No visible defect \\
2 & Pitting \\
3 & Fretting \\
4 & Micro fractures \\
5 & Complete fracture \\
6 & Metal flash \\
7 & Metal strips \\
8 & Blunt cutting edges \\
9 & Disruption of cutting edge \\
10 & Corrosion \\
11 & Debris \\
\hline
\end{tabular}

Table 4: Corrosion and surface damage scores for each sample (sum of values for all changes on the surface of the file according to Eggart scoring system)

\begin{tabular}{lll}
\hline Sample & Observer 1 & Observer 2 \\
\hline A1 & 31 & 27 \\
A3 & 34 & 27 \\
A4 & 43 & 39 \\
B1 & 23 & 23 \\
B5 & 27 & 27 \\
B6 & 30 & 30 \\
C1 & 39 & 36 \\
C4 & 30 & 30 \\
C6 & 27 & 27 \\
D2 & 19 & 19 \\
D4 & 21 & 21 \\
D6 & 16 & 16 \\
\hline
\end{tabular}

Table 5: Mean value of corrosion and surface damage scores based on 4 groups

\begin{tabular}{lllll}
\hline Group & Mean value & $\begin{array}{l}\text { Standard } \\
\text { deviation }\end{array}$ & Minimum & Maximum \\
\hline I & 36 & 6.245 & 31 & 43 \\
II & 26.6667 & 3.51188 & 23 & 30 \\
III & 32 & 6.245 & 27 & 39 \\
IV & 18.6667 & 2.51661 & 16 & 21 \\
\hline
\end{tabular}

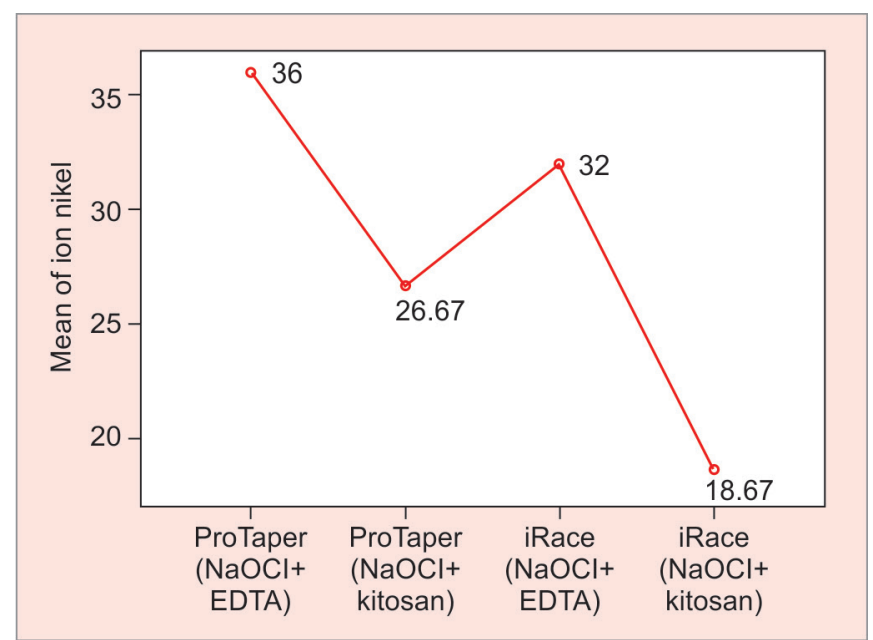

Fig. 6: Mean value of corrosion and surface damage scores based on 4 groups
Table 6: LSD test of corrosion and surface damage score

\begin{tabular}{lllll}
\hline Group & I & II & III & IV \\
\hline I & - & & & \\
II & 0.049 & - & & \\
III & 0.348 & 0.221 & - & \\
IV & 0.003 & 0.081 & 0.011 & - \\
\hline
\end{tabular}

immersion with $17 \%$ EDTA for 5 minutes caused a significantly increase in surface roughness compared to $\mathrm{NaOCl}$. This may be due to EDTA $\mathrm{pH}$ being lower than $\mathrm{NaOCl} \mathrm{pH} .{ }^{26}$ Treacy et al. stated that EDTA acts as a cathodic stimulant inducing high rates of corrosion even in the absence of oxygen and presented that the presence of EDTA in neutral and alkaline solutions accelerates the rate of dissolution of metals. ${ }^{27}$

The result of this study indicated that the combination of $2.5 \% \mathrm{NaOCl}$ and $0.2 \%$ high molecular chitosan solution resulted in significantly lower corrosive and surface damage than the combination of $2.5 \% \mathrm{NaOCl}$ and $17 \%$ EDTA in ProTaper and iRace rotary files. Chitosan has good binding ability with metal ions due to its amine group which is responsible for taking metal cations through the chelation process. Metal cation absorption utilizes the presence of free electron pairs in the $-\mathrm{OH}$ and $-\mathrm{NH}_{2}$ groups. The electron pairs in the $-\mathrm{OH}$ and $-\mathrm{NH}_{2}$ group will act as ligands that can interact with metal cations through the mechanism of covalent bonding. Chitosan in neutral $\mathrm{pH}$ is able to complex dangerous metal ions. ${ }^{28}$ Several studies have reported the use of chitosan as a coating to improve surface corrosion resistance in NiTi alloy. Ahmed et al. with elemental analysis stated that NiTi alloys coated with chitosan had less release of nickel ions compared to uncoated $\mathrm{NiTi}$ alloys. According to Goryczka et al., coating chitosan did not cause structural changes in the alloy $\mathrm{NiTi}$ and maintained the character and the reversibility of the martensitic transformation. ${ }^{29,30}$

Stokes et al. described pitting corrosion of the file surface after 1 hour of immersion in $5.25 \% \mathrm{NaOCl}$ and speculated that manufacturing factors affect the corrosion of NiTi endodontic instruments. This study used a crown down pressureless technique to prepare the root canal systems and compared between ProTaper Universal and iRace rotary files against corrosion and surface damage scores. The mean values of corrosion and surface damage scores in iRace were lower than those in ProTaper Universal rotary files using either a combination of $2.5 \% \mathrm{NaOCl}$ and $17 \%$ EDTA or $2.5 \% \mathrm{NaOCl}$ and $0.2 \%$ high molecular chitosan solution. This result was in accordance with Sood et al. which showed that ProTaper causes maximum corrosion compared to iRace. This can be due to machining marks on the file surface that act as crevices and initiate corrosion. RaCe files showed relatively less corrosion when compared to ProTaper. This is speculated to be due to grinding and mechanical polishing done during the manufacturing process to remove machining marks. Also, the file coated with silver nitride increases the hardness and is more resistant toward corrosion. ${ }^{31}$

This study also compared the effect of the combination of $2.5 \% \mathrm{NaOCl}$ and $17 \%$ EDTA with $2.5 \% \mathrm{NaOCl}$ and $0.2 \%$ high molecular chitosan solution during the preparation of the root canal system using ProTaper Universal and iRace rotary files on the apical extrusion of nickel ions using AAS. The combination of $2.5 \%$ $\mathrm{NaOCl}$ and $0.2 \%$ high molecular chitosan solution resulted in less extruded nickel ions compared to the combination of $2.5 \% \mathrm{NaOCl}$ and $17 \%$ EDTA on ProTaper Universal and iRace rotary files. This was possible because the combination of $2.5 \% \mathrm{NaOCl}$ and $0.2 \%$ 
high molecular chitosan solution caused a lower corrosive effect (according to the mean value of corrosion and surface damage score in this study), resulting in a slight release of nickel ions compared to the combination of $2.5 \% \mathrm{NaOCl}$ and $17 \%$ EDTA. The result of this study was also the same as the result of Anggi and Trimurni which showed that $0.1 \%$ and $0.2 \%$ chitosan solution resulted in smaller debris extrusion compared to $2.5 \% \mathrm{NaOCl}$ and $17 \%$ EDTA, and the combination of $17 \%$ EDTA and $2.5 \% \mathrm{NaOCl}$ resulted in up to 2 times more extrusion of debris. ${ }^{32}$

In this study, iRace produced less extrusion of nickel ions compared to ProTaper Universal rotary files using either a combination of $2.5 \% \mathrm{NaOCl}$ and $17 \%$ EDTA or $2.5 \% \mathrm{NaOCl}$ and $0.2 \%$ high molecular chitosan solution. This result was the same as Nagaveni et al. which concluded that RaCe extruded the least debris extrusion compared to ProTaper, Hero-Shaper, and K3 rotary systems. RaCe instruments have a nonconvex triangular crosssectional design, smaller core diameter, and short twisted cutting edges alternating with straight edges which allows more space to carry debris out toward the orifice thus avoiding its compaction in the root canal while ProTaper universal instruments have a convex triangular cross-section and their debris space is smaller than RaCe. ProTaper system leads to a significantly large amount of extruded debris due to faster, aggressive system with its characteristic design features, which removes a substantial amount of dentin in a shorter period of time, and is unable to displace the debris coronally with the same efficiency as it cuts, thus poses an increased risk of debris and irrigant apical extrusion. Also, the long pitch design of the ProTaper instruments might cause a greater amount of debris extrusion. ${ }^{20,33,34}$

In this study, the quantity of extruded nickel ions is still within the threshold that can be tolerated by the body (the estimated maximum nickel that can be received by the body is $200-300 \mu \mathrm{g}$ per day). But increasing the amount of nickel in the body can also be related to environmental exposure (air), food, drinks, smoking, and skin contact. In addition, nickel ions extruded from the apical foramen will enter the blood vessels in the periapical region that contain many cells such as vascularized periodontal ligaments, then spread through the systemic circulation, and enter the organs, so it is important to minimize the number of extruded nickel ions from the apical foramen when preparing the root canal systems.

\section{Conclusion}

According to all benefits found in $0.2 \%$ high molecular chitosan solution, $0.2 \%$ high molecular chitosan solution can be developed as a chelating material, an alternative to EDTA. Using instruments and irrigants that can minimize apical extrusion will be an advantage both for practitioners and patients.

\section{Clinical Significance}

Using instruments and irrigant that can minimize apical extrusion will be an advantage both for practitioners and patients.

\section{References}

1. Young GR, Parashos $P$, et al. The principles of technique for cleaning root canals. Aust Dent J Suppl 2007;52(1):52-63. DOI: 10.1111/j.18347819.2007.tb00526.x.

2. Prasad PS, Sam JE, et al. The effect of $5 \%$ sodium hypochlorite, 17\% EDTA and Triphala on two different rotary NiTi instruments: an AFM and EDS analysis. J Conserv Dent 2014;17(5):462-466. DOI: 10.4103/0972-0707.139842.

3. Ruddle CJ. The ProTaper advantages: shaping the future of endodontics. Adv Endod 2001;1-9.

4. Saber SE, Nagy MM, et al. Comparative evaluation of the shaping ability of ProTaper Next, iRace and Hyflex CM rotary NiTi files in severely curved root canals. Int Endod J 2015;48:131-136. DOI: 10.1111/ iej.12291.

5. Siqueira JF, Lopes HP. Chemomechanical preparation. Treatment of endodontic Infections. Berlin: Quintessence Publishing; 2011.

6. Can EDB, Kazandag MK, et al. Inadvertent apical extrusion of sodium hypochlorite with evaluation by dental volumetric tomography. Hindawi Publishing Corporation; 2015. pp. 1-7.

7. Glassman G. Safety and efficacy considerations in endodontic irrigation. ADA Cerp; 2011, www.ineedce.com.

8. Zaparolli D, Saquy PC, et al. Effect of sodium hypochlorite and EDTA irrigation, individually and in alternation, on dnetin microhardness at the furcation area of mandibular molars. Braz Dent J 2012;23(6): 654-658. DOI: 10.1590/S0103-64402012000600005.

9. Garg N, Garg A. Textbook of Endodontics, 2nd ed. New Delhi: Jaypee; 2010. pp. 210-230.

10. Baumgartner JC, Ibay AC. The chemical reactions of irrigants used for root canal debridement. J Endod 1987;13(2):47-51. DOI: 10.1016/ S0099-2399(87)80153-X

11. Hulsmann $M$, Hahn W. Complications during root canal irrigation. Int Endod J 2000;33(3):186-193. DOI: 10.1046/j.1365-2591.2000.00303.x.

12. Zaparolli D, Saquy PC, et al. Effect of sodium hypochlorite and EDTA irrigation, individually and in alternation, on dnetin microhardness at the furcation area of mandibular molars. Braz Dent J 2012;23(6): 654-658. DOI: 10.1590/S0103-64402012000600005.

13. Sugita P, Sjahriza A, et al. Chitosan: sumber biomaterial masa depan. Bogor: Penerbit IPB Press; 2009.

14. Trimurni A, Harry A, et al. Laporan akhir penelitian riset pembinaan Iptek kedokteran 2006/2007. Medan: Fakultas Kedokteran Gigi USU; 2006. pp. 16-18.

15. Mira PCS, Souza-Flamini LE, et al. Evaluation of the chelating effect of chitosan solubilized in different acids. J Conserv Dent 2017;20(5): 297-301.

16. Trimurni AD. Effect of irrigation with chitosan high molecule, sodium hypochlorite and edta to remove smear layer (in vitro). USU 2015;48-55.

17. Pimenta JA, Zaparolli JD, et al.Chitosan:Effect of a New Chelating Agent on the Microhardness of Root Dentin. Braz Dent J 2012;23(3):212-217.

18. Popovic J. The examination of sensitivity to corrosion of nickel titanium and stainless steel endodontic instruments in root canal irrigating solution. Chem Ind Chem Eng Q 2016;22(1):95-100.

19. Mohammadi Z, Soltani MK, et al. A review of the various surface treatments of NiTi instruments. Iran Endod J 2014;9(4):235-240.

20. Tamer AA. An in vitro comparison of apically extruded debris using three rotary instrumentation systems. J Dent Sci 2010;5(3):121-125.

21. Kucukyilmaz E, Savas S, et al. Assessment of apically extruded debris and irrigant produced by different nickel titanium instrument systems. Braz Oral Res 2015;29(1):1-6.

22. Das KK, Das SN, et al. Nickel, its adverse health effects \& oxidative stress. Indian J Med Res 2008;128:412-425.

23. Dagna A. Cyclic fatigue resistance of three NiTi single-file systems after immersion in EDTA. Dentistry 2014;4(1):1-4.

24. Yum JW, Park JK, et al. Comparative analysis of various corrosive enviromental conditions for NiTi rotary files.2008, golddent@pusan. ac.kr.

25. Ametrano G, D'Antò V, et al. Effect of sodium hypochlorite and ethylenediaminetetraacetic acid on rotary nickel titanium instruments evaluated using atomic force microscopy. Int Endod J 2011;44:203-209.

26. Cai JJ, Tang XN, et al. Effect of irrigation on surface roughness and fatigue resistance of controlled memory wire nickel titanium instruments. Int Endod J 2017 Jul;50(7):718-724. DOI:10.1111/iej.12676. 
27. Treacy GM, Rudd AL, et al. Electrochemical Behavior of aluminium in the presence of EDTA-containing chloride solutions. J Appl Electrochem 2000;30:675-683.

28. Sugita P, Sjahriza A, et al. Chitosan: sumber biomaterial masa depan. Bogor: Penerbit IPB Press; 2009.

29. Ahmed RA, Fadl-allah AD, et al. Improvement of corrosion resistance and antibacterial effect of NiTi orthopedic materials by chitosan and gold nanoparticles. Appl Surf Sci 2014;292:390-399.

30. Goryczka T, Anna K, et al. Martensitic transformation and shape memory effect in NiTi alloy covered by chitosan/silver layer. 2015;33:1-6. DOI: 10.1051/matecconf/20153303012.
31. Sood K, Mohan B, et al. Effect of cleaning and sterilization procedures on NiTi rotary files-an SEM and EDS study. Endod 2007;34-41.

32. Trimurni AD. Perbedaan Jumlah Ekstrusi Debris Antara Chitosan Blangkas Molekul Tinggi dengan Sodium Hipoklorit pada Tindakan Irigasi Saluran TR E. Int Endod J 2006;39:693-699.

33. Nagaveni SA, Balakoti KR, et al. Quantitative Evaluation of Apical Extrusion of Debris and Irrigants using Four Rotary Instrumentation Systems: An in vitro Study. J Contemp Dent Pract 2013;14(6):1065-1069.

34. Logani A, Shah N. Apically extruded debris with contemporary NiTi instrumentation systems: an ex vivo comparative study. Indian J Dent Res 2008;19(3):182-185. 